Mеталлофиз. новейшие технол. / Metallofiz. Noveishie Tekhnol. (C) 2015 ИМФ (Институт металлофизики 2015, т. 37, № 4, сс. 571-579

Оттиски доступны непосредственно от издателя

им. Г. В. Курдюмова НАН Украины)

Фотокопирование разрешено только

Напечатано в Украине.

в соответствии с лицензией

PACSnumbers: 61.72.Ff, 61.72.Hh, 61.72.Mm, 62.20.F-, 62.23.St, 81.20.Hy, 83.50.Uv

\title{
Structural Modification of AD-1 Aluminium Alloy by the Method of Cold Rolling with Shift
}

V. M. Varyukhin, O. G. Pashinska, V. M. Tkachenko, V. V. Burkhovetskii, and A. V. Zavdoveev

O. O. Galkin Donetsk Physicotechnical Institute, N.A.S. of Ukraine, 72 Rosa Luksemburg Str., 83114 Donetsk, Ukraine

The method of rolling with shift in comb-shaped calibres for a bar is developed in order to create the conditions of severe deformation in the processed AD-1 aluminium alloy. The method provides formation of a structural state with the controlled fraction of nanostructure. As shown, the rolling with shift results in intensive fragmentation of the structure and reduction of the anisotropy of the material properties in different sections of the billet, as compared to the conventional rolling.

Розвинуто методу вальцювання зі зсувом у калібрах з гребінчастою поверхнею для смуги, що уможливлює створити умови інтенсивної деформації в оброблюваному алюмінійовому стопі АД-1. Метода забезпечує формування структурного стану з регульованою часткою наноструктури. Показано, що вальцювання зі зсувом спричиняє інтенсивну фрагментацію структури і зниження анізотропії властивостей матеріялу в різних перетинах заготівки в порівнянні з прокаткою за стандартною технологією.

Развит метод прокатки со сдвигом в калибрах с гребенчатой поверхностью для полосы, что позволяет создать условия интенсивной деформации в обрабатываемом алюминиевом сплаве АД-1. Метод обеспечивает формирование структурного состояния с регулируемой долей наноструктуры. Показано, что прокатка со сдвигом приводит к интенсивной фрагментации структуры и снижению анизотропии свойств материала в разных сечениях заготовки в сравнении с прокаткой по стандартной технологии.

Key words: structure, anisotropy, severe plastic deformation, rolling, EBSDanalysis, aluminium alloy.

(Received November 9, 2014; in final version, December 8, 2014) 


\section{INTRODUCTION}

Scientific centres of the USA, Germany, Russia, and Ukraine take leading positions in the world on research and development of structural modification of promising and functional structural materials. For the purpose to enhance physical and mechanical characteristics of materials, the considerable attention is paid to a problem of producing of materials with the changed ratio hardness-plasticity by means of methods of an intensive plastic deformation (IPD). In these latter days, IPD methods are widely applied for the solution to this problem by an equal channel angular pressing [1-5], a screw extrusion [6-9], rolling [10], etc. [1, 11, 12]. However, until now, the problem of production of materials with new properties in mass amounts for application in the industry is not solved.

For production of materials with the changed ratio of strength and plastic properties and a controlled fraction of a nanostructure, authors of Refs. [13-19] develop the combined methods of deformation treatment. These combined treatments superimpose the shift component of deformation. In this paper, the new method of rolling with shift for the bar or foil production is considered. The developed method of rolling with shift represents an advanced standard rolling practice, in which due to an additional overflow of metal crosswise (concerning an axis of rolling) additional shift stresses appear.

The investigations performed in this work are pointed at detection of effects of structural modification of the aluminium alloy after rolling with shift and study of physical-mechanical properties of the material. Determination of regularities of formation of the structurally modified state in the aluminium alloy by application of rolling with shift, in comparison with the traditional procedure is also of interest.

\section{MATERIAL AND EXPERIMENTAL TECHNIQUE}

Samples from the AD-1 aluminium alloy of the following chemical composition: $\mathrm{Al}-\min 99.3 \%, \mathrm{Si}-$ up to $0.3 \%, \mathrm{Fe}-$ up to $0.3 \%, \mathrm{Cu}-$ up to $0.05 \%, \mathrm{Mn}-$ up to $0.025 \%, \mathrm{Mg}$ - up to $0.05 \%, \mathrm{Zn}$ - up to $0.1 \%$, and $\mathrm{Ti}-$ up to $0.15 \%$ are applied in the capacity of the investigated material. Samples for investigation represent the bar produced after rolling. The cast rod of $25 \mathrm{~mm}$ in diameter, annealed at the temperature of $673 \mathrm{~K}$ within 1 hour served as a rolling billet. The initial size of grain before rolling was 15 microns.

For production of a bar, rolling was fulfilled in calibres with a comb surface at the temperature of $300 \mathrm{~K}$. The part blank was multiply deformed in systems of calibres that had allowed realizing dislocation modification for formation of structure with the changed relation hardness-plasticity. Rolling was carried out on a rolling mill 100 . The 
nominal diameter of a barrel of rolls is $100 \mathrm{~mm}$, barrel width-200 $\mathrm{mm}$, a material of rolls-steel 45, HRC $25-30$. The rolling speed on the mill was controlled from 0 to $0.2 \mathrm{~m} / \mathrm{s}$ (rolls rotated with rotation rate from 0 to $40 \mathrm{rpm}$ ). Engine capacity is $1.5 \mathrm{~kW}$. Rotation transfer to rolls was carried out through a gearbox and a pinion stand.

Rolling for bar production was fulfilled by two regimes. The first regime was carried out according to standard techniques on flat rolls. The second regime was performed according to techniques of deformation with shift with serial use of rolls with longitudinal grooves and flat rolls.

Microscopic structure of the annealed and deformed samples was investigated with use of raster-type electron microscope JSM-6490LV by the method of diffraction of back reflected electrons (EBSDanalysis). The quantitative estimation of grain sizes and their fragments was performed on the samples, which have been cut out in a rolling plane. The sample preparation was carried out on the standard procedure. The solution on the basis of phosphoric acid, chromic anhydride and distilled water was applied for electropolishing.

Microhardness was measured using PMT-3 device with diamond pyramidal indenter. The measuring error comprised $5 \%$.

The measurements of samples density was performed by the method of volume determination by Archimedes' principle using AX-200 scales of Shimadzu firm.

\section{EXPERIMENYAL RESULTS AND DISCUSSION}

Investigations of structure and properties of the aluminium alloy were carried out in the initial annealed state, after rolling with shift and after rolling by the standard techniques. In Figure 1, EBSD-charts of crystallographic orientations of building blocks of the aluminium alloy after different types of treatment are presented.

In an initial state, the aluminium alloy is characterized by equiaxial

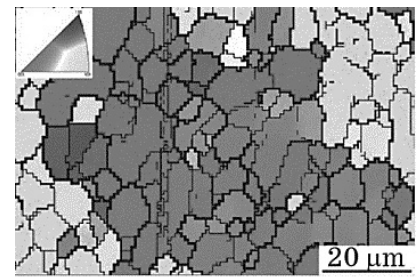

$a$

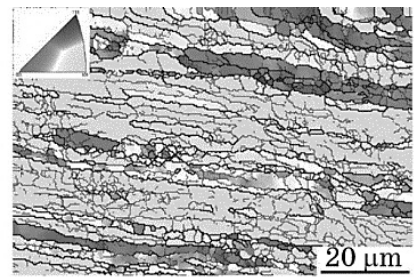

$b$

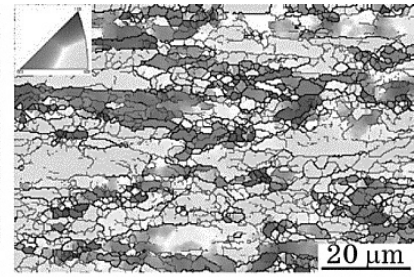

$c$

Fig. 1. EBSD-charts of crystallographic orientations of the building blocks of the aluminium alloy after annealing $(a)$, rolling by the standard techniques (b), and the rolling with shift (c). 

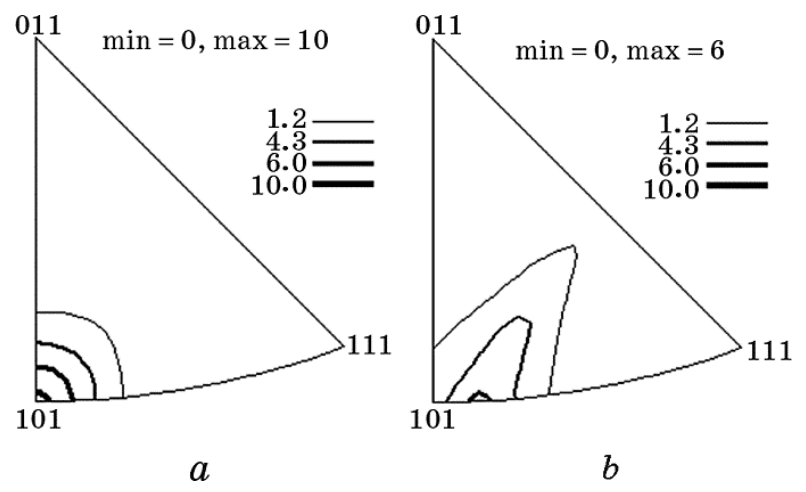

Fig. 2. Inverse pole figures for the aluminium alloy after rolling by the standard techniques $(a)$ and the rolling with shift $(b)$.

grain structure with the medium size of 15 microns. Grains of the material do not have preferred crystallography orientation.

At rolling by the standard techniques, the shape of grains varies in accordance with the applied load axis. Grains are drawn down in a rolling direction and reduce their sizes in width. The length of grains makes 27.5 microns, and their width makes 3.6 microns. Building blocks get preferential crystallographic orientation; the most part of them is oriented by planes $\{\mathbf{1 0 1}\}$ in parallel with the rolling plane.

Introduction of an additional shifting at the rolling with shift promotes decrease of the structure anisotropy. Grains become less stretching down (average length of grains is $\mathbf{1 6 . 9}$ microns) and wider (average size in width is 4.8 microns). Small equiaxial grains appear with the average length of 1.8 microns, which are concentrated in deformation bands. In comparison with rolling by the standard techniques, a number of the building blocks in the material with planes $\{101\}$, located in parallel with the rolling plane, is decreased. More grains with other crystallographic orientations are observed.

The analysis of texture of the aluminium alloy has shown decrease of anisotropy of crystallographic orientations of crystallites at the rolling with shift, in comparison with rolling by the standard techniques (see Fig. 2). In the samples deformed by the rolling at the standard techniques, distribution of directions on inverse pole figures are concentrated near projection of planes $\{101\}$ (see Fig. 2, a). At the rolling with shift, the intensity of the textural maximums decreases approximately twice and the texture degradation takes place (see Fig. 2, b).

In Figure 3, distribution of boundaries of building blocks of the aluminium alloy depending on the treatment type is shown. Boundaries of building blocks with small-angle disorientation $\left(<15^{\circ}\right)$ are marked by grey lines; black lines correspond to high-angle grain boundaries $\left(15^{\circ}-\right.$ $60^{\circ}$ ). The analysis of boundaries of the building blocks of the material 


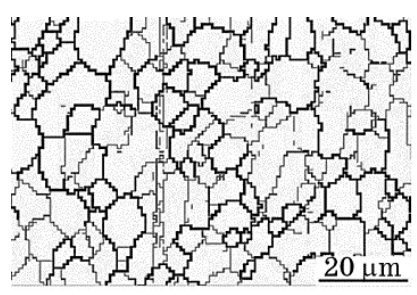

$a$

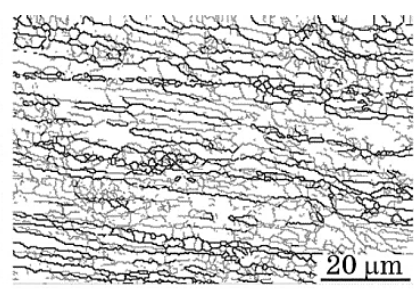

$b$

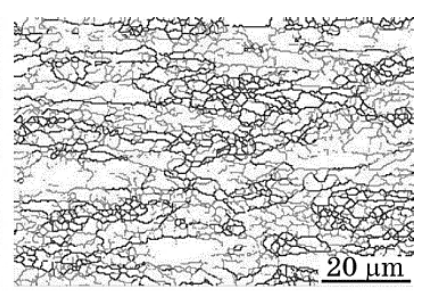

$c$

Fig. 3. EBSD charts of distribution of building blocks boundaries of the aluminium alloy after annealing $(a)$, rolling by the standard techniques $(b)$ and the rolling with shift $(c)$.

after the rolling with shift has shown that inside of grains surrounded by high-angle grain boundaries the considerable quantity of unclosed small-angle boundaries is present in addition to boundaries of subgrains (see Fig. 3, c). It testifies that during the rolling with shift the redistribution of dislocations takes place; therefore, dislocations are up-built in dislocation walls. Dislocation walls can transform in smallangle boundaries under condition of the further accumulation of dislocations and their ordering.

After the rolling with shift, more equiaxial fine grains are formed in the structure, than at the rolling by the standard techniques (see Fig. $3, b)$. In main, these grains are surrounded by the high-angle boundaries.

During the deformation treatment, formation of fine grains with the average size of 1.8 microns takes place at a fragmentation of bigger grains. The fragmentation of the coarse grains is carried out due to accumulation of dislocations and their reorganization into dislocation substructures. These substructures break down coarse grains into cells, disoriented from each other by some angles. The more dislocations are contained within boundaries of the cells, the bigger angle of disorientation among cells takes place [20]. The grains formed due to fragmentation have the deformed crystal lattice and can contain a dislocation substructure (see Fig. 4 (are selected by grey and light grey colour)).

Development of relaxation processes during deformation, such as a dynamic recrystallization $[14,21]$ can be another reason for appearance of fine grains. In this case, grains with a size less than $4 \mu \mathrm{m}$ are formed, which are surrounded by the high-angle boundaries and do not contain the dislocation substructure inside (Fig. 4, $a, b$ (are selected by dark grey colour)).

By means of the EBSD-analysis, the estimate of the structural condition of grains of the aluminium alloy depending on the treatment type (see Fig. 5) is performed. The obtained data confirm a hypothesis 


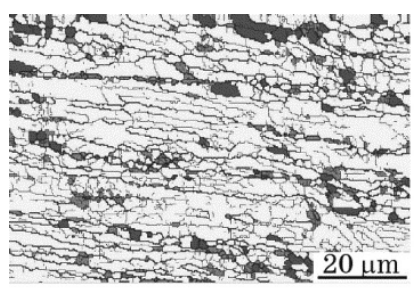

$a$

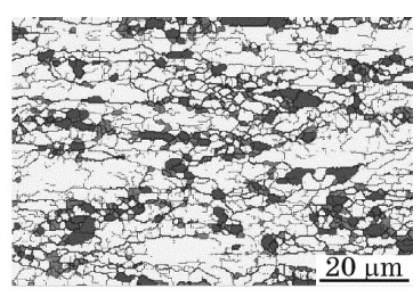

$b$

Fig. 4. EBSD charts of the structural condition of grains of the aluminium alloy after the rolling by the standard techniques $(a)$ and the rolling with shift (b). Light grey-polygonised grains, grey-fragmented grains, dark greyrecrystallized grains.

concerning the development of relaxation processes.

In comparison with rolling by the standard techniques, at the rolling with shift, the number of recrystallized grains is doubled, the number of fragmented grains increases at $\mathbf{1 . 2 5}$ times, and the number of polygonised grains decreases in 1.1 times. It means that the structure of the material after deformation with adding of the shift component has more perfect structure than the structure produced by the standard treatment schema.

More intensive development of relaxation processes at the rolling with shift results in decrease of a number of defects in the material, which are formed during deformation. As a result, the material has higher value of density than after rolling by the standard techniques (see Fig. 6).

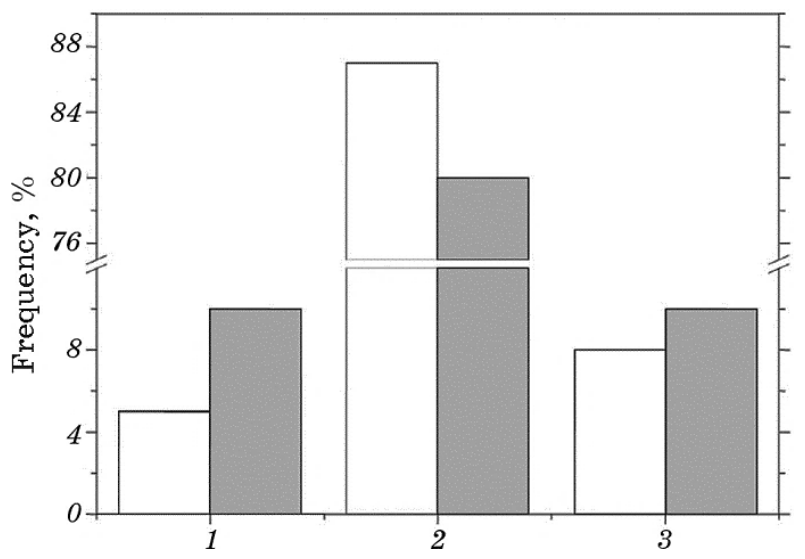

Fig. 5. Quantitative analysis of recrystallized grains (1), polygonised grains (2), and fragment grains (3) after the rolling by the standard techniques (white) and the rolling with shift (grey). 


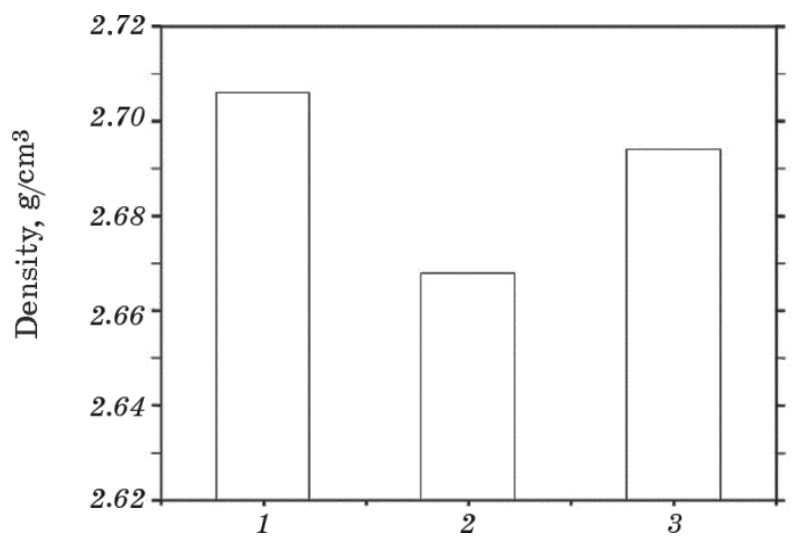

Fig. 6. Aluminium alloy density in the initial state (1), after rolling by the standard techniques (2), and the rolling with shift (3).

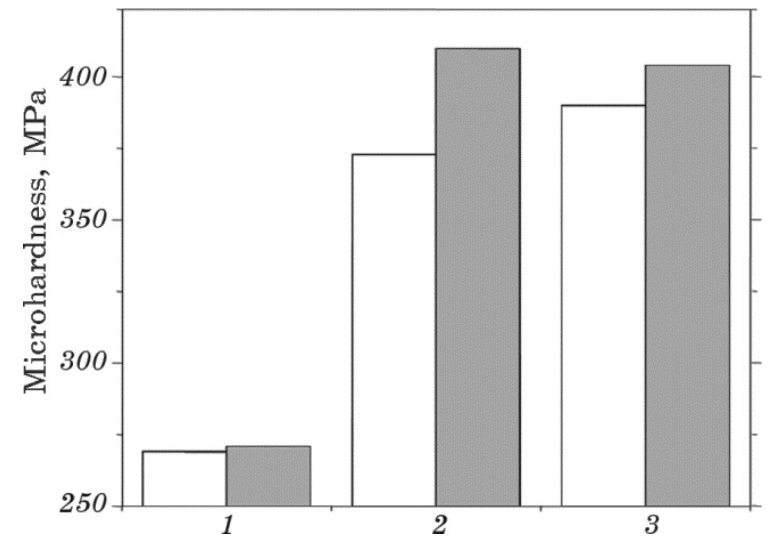

Fig. 7. The aluminium alloy microhardness in the initial state (1), after rolling by the standard techniques (2) and the rolling with shift (3) in cross-sections, perpendicular (white) and parallel (grey) to the rolling direction.

In Figure 7, values of the microhardness of the aluminium alloy are presented at different types of treatment for cross-sections of the samples, which are parallel and perpendicular to the rolling direction. In the cross-section, perpendicular to a deformation direction, for the rolling with shift values of the microhardness are higher than values for the standard rolling. In the cross-section parallel to the rolling direction, values of the microhardness are higher for the material treated by the standard rolling.

As a result, the samples deformed by different types of rolling, have about equal average value of the microhardness on all cross-sections. However, at the rolling with shift the decrease of the microhardness 
anisotropy is observed. At this type of deformation, samples have a smaller difference between values of the microhardness in different cross-sections, in comparison with rolling by the standard techniques.

\section{CONCLUSIONS}

It is shown that the formation of structure of the aluminium alloy at cold rolling with shift proceeds under the influence of processes of the fragmentation, polygonization, and dynamic recrystallization. It results in formation of a structure of the mixed type, consisting of grains of several types: small fragment grains with high-angle boundaries and high density of dislocations in a body of grain, small recrystallized grains with high-angle boundaries and the small dislocation density in the grain body, and large polygonised grains with the average dislocation density.

Introduction of the additional shifting at the rolling results in the intensive fragmentation of the structure and promotes development of relaxation processes of the dynamic recrystallization type during deformation. Development of this mechanism results in the growth of the number of recrystallized grains and to higher density of the material in comparison with the standard techniques.

Decrease of the intensity of crystallographic texture and its diffusion in the aluminium alloy deformed by the rolling with shift, promotes decrease of anisotropy of properties of the material in different cross-sections of the billet, in comparison with the rolling by the standard techniques.

\section{REFERENCES}

1. R. Z. Valiev and I. V. Aleksandrov, Bulk Nanostructured Metallic Materials: Production, Structure and Properties (Moscow: Akademkniga: 2007) (in Russian).

2. V. M. Segal, Mater. Sci.Eng., A, 476, Nos. 1-2: 178 (2008).

3. P. J. Apps, M. Berta, and P. B. Prangnell, Acta Mater., 53, No. 2: 499 (2005).

4. E. A. El-Danaf, M. S. Soliman, A. A. Almajid, and M. M. El-Rayes, Mater. Sci. Eng. A, 458, Nos. 1-2: 226 (2007).

5. $\quad$ E. A. El-Danaf, Mater. Design, 32, No. 7: 3838 (2011).

6. Y. Beygelzimer, V. Varyukhin, D. Orlov, and S. Synkov, Twist ExtrusionProcess for Deformation Accumulation (Donetsk: TEAN: 2003).

7. M. M. Myshlyaev, M. M. Kulak, and E. G. Pashynskaya, Nanostructurnoe Materialovedenie, 8, No. 1: 217 (2010) (in Russian).

8. V. M. Varyukhin, O. G. Pashinska, V. M. Tkachenko, and M. M. Myshlyaev, Metallofiz. Noveishie Tekhnol., 34, No. 12: 1655 (2012) (in Russian).

9. E. Pashinska, V. Varyukhin, and S. Dobatkin, Emerging Materials Research, 2, No. 3: 121 (2013).

10. Y.S. Kim, S. H. Kang, and D. H. Shin, Mater. Sci. Forum, 503-504: 681 
(2006).

11. A. P. Zhilyaev and T. G. Langdon, Prog. Mater. Sci., 53: 893 (2008).

12. G. A. Salishev, O. R. Valiakhmetov, and R. M. Galeyev, J. Mater. Sci., 28: 2898 (1993).

13. A. Gholinia, F. J. Humphreys, and P. B. Prangnell, Acta Mater., 50, No. 18: 4461 (2002).

14. E. Pashinskaya, Physical and Mechanical Base of Structure Evolution at Combined Plastic Deformation (Donetsk: Veber: 2009).

15. A. B. Lopes, F. Barlat, J. J. Gracio, J. F. Ferreira Duarte, and E. F. Rauch, Int. J. Plasticity, 19, No. 1: 1 (2003).

16. E. G. Pashynskaya, M. M. Myshlyayev, V. N. Varyukhin, V. V. Stolyarov, S. A. Mironov, and V. M. Tkachenko, Bull. Russ. Acad.Sci.: Phys., 73, No. 9: 1249 (2009).

17. V. M. Varyukhin, N. N. Belousov, O. G. Pashins'ka, and V. M. Tkachenko, Metallofiz. Noveishie Tekhnol., 27, No. 8: 1113 (2005) (in Russian).

18. V. N. Varyukhin, E. G. Pashinskaya, V. M. Tkachenko, and M. M. Bilousov, Mater. Sci. Forum, 503-504: 591 (2006).

19. E. G. Pashinskaya and A. A. Tolpa, Metally, No. 5: 85 (2004) (in Russian).

20. E. V. Kozlov, A. N. Zhdanov, and N. A. Koneva, Phys. Mesomech., 11, Nos. 1-2: 42 (2008).

21. V. M. Varyukhin, O. G. Pashinska, M. M. Myshlyayev, V. V. Stolyarov, V. M. Tkachenko, and I. I. Tyshchenko, Metallofiz. Noveishie Tekhnol., 31, No. 10: 1399 (2009) (in Russian). 